\title{
Kinetics of dehydration of potato and development of baked product based on dehydrated potato
}

\author{
A. Sarker ${ }^{1}$, M. N. Islam ${ }^{2}$ and M. R. Shaheb ${ }^{3}$ \\ ${ }^{1}$ Department of Food Engineering and Tea Technology, Shahjalal University of Science and Technology (SUST), \\ Sylhet-3100, Bangladesh, ${ }^{2}$ Department of Food Technology and Rural Industries, Bangladesh Agricultural University \\ (BAU), Mymensingh-2202, Bangladesh and ${ }^{3}$ On-Farm Research Division (OFRD), Bangladesh Agricultural Research \\ Institute (BARI), Sylhet-3100, Bangladesh. Email: ayesha_sust85@yahoo.com
}

\begin{abstract}
The aims of this study were to determine the kinetics of dehydration of high yielding potato variety (Diamont), to investigate the various process parameters influencing mechanical drying of potatoes and to develop baked product from the dehydrated potato. From the developed equation it was found that the diffusion co-efficient increased with the increase in temperature. The exponential relationship between diffusion co-efficient $\left(D_{e}\right)$ versus inverse absolute temperature $\left(T_{a b s}{ }^{-1}\right)$, activation energy $\left(E_{a}\right)$ for diffusion of water HYV potato was found to be $7.98 \mathrm{Kcal} / \mathrm{gm}$-mole. The influence of loading density as well as thickness of the product on drying rate were determined and the power law equations which described the relationship between drying rate constant and thickness gave an n-value of 0.4586 for HYV of potato. Organoleptic taste tests demonstrated that among biscuits made of various proportion of potato flour and wheat flour, the results of test panel showed that biscuit made of equal proportion (1:1) of potato flour and wheat flour secured the highest score (8.0). All the other samples of each type of product were also accepted by the panelists either as "like moderately" or "like slightly".
\end{abstract}

Keywords: Activation energy, Baked products, Diffusion co-efficient, Kinetics of dehydration, Loading density

\section{Introduction}

Potato (Solanum tuberosum L.) is one of the important vegetables as well as cash crop in Bangladesh. Bangladesh ranks 11 in the world in terms of potato production in 2008 (Hossain and Miah, 2010). The annual growth rates of area, production and yield of potato were estimated at $7.14 \%, 9.90 \%$ and $2.76 \%$ during 1989-1990 to 2008-2009, respectively (Miah et al., 2011). The production to potato in the year 2009-10 was 0.79 million tones (BBS, 2010). Both production and consumption of potato are accelerating in most of the developing countries and it is expected that the trend will continue for the years to come (www.sfaeindia.com). With its ever increasing population, the food crisis will be more acute in the near future. To cope this situation, the potato can play vital role in providing food security and alleviating poverty of the population and for increasing production of food and it's diversified uses are to be boosted up at an accelerated rate. For solving these problems we can produce varieties of value-added potato products, which are more attractive and favorite foods to the consumers. Considering the importance, FAO designated 2008 as the "International Year of Potato (IYP)" to raise the profile of this globally important food crop and commodity, giving emphasis to its biological and nutritive attributes towards meeting the "Millennium Development Goals" (FAO, 2008). Potato can be preserved for long term use and consumed in large quantities in different forms such as biscuits, bread, chapatti, powder supplement to dal etc. Supplementing cereal diets such as rice greatly improves the nutritive value of the diet as potato supplies lysine, the limiting essential amino acid of cereals while the cereals, in turn, supply cystine and methionine, the limiting essential amino acids of potato (Islam, 1980).

Global consumption is shifting from fresh potatoes to value-added processed products. Potato flour is the oldest commercial processed potato product. It is widely used by the baking industry. Manufacture of potato flour since the drum drier equipped with applicator roll was very popular. However, the rapid expansion of the potato processing industry, the alternative methods of drying of potato as slice or dice in cabinet, tunnel or conveyor drier has been reported (Islam, 1980). USPB (2005) reported that dehydrated potato products can be used as a nutritious base food and a neutral product that complements a variety of ingredients. The potato powder was obtained by drum dryer using different process parameters (temperature, time and product thickness) to minimize thermal damage on the final product and the results showed that the lower the process temperature, the better the powder quality (Carillo et al., 2009). Falade and Solademi (2010) observed the effect of blanching, drying temperatures $\left(50-80^{\circ} \mathrm{C}\right)$ and thickness $(5,10$ and $15 \mathrm{~mm})$ on drying characteristics of sweet potato slices. They reported that diffusion coefficient $\left(D_{\text {eff }}\right)$ increased with increasing thickness and air temperature. McMinn and Magee (1997) 
calculated effective moisture diffusivity (EMD) and shrinkage occurring during drying of potato at air temperature of $60^{\circ} \mathrm{C}$ with air velocity of 0.5 to $1.5 \mathrm{~m} / \mathrm{s}$ and they found that drying process appeared to be completely controlled by internal resistance to mass transfer. Temperature had the major influence on drying while flow rate showed a limited effect. Considering the above factors and background information, the present study was undertaken with the following objectives: i) to determine the proximate composition of HYV potato (var. Diamont); ii) to analyze the kinetics of dehydration of potato at low air dry bulb temperature using a mechanical dryer and iii) to develop baked product (biscuit) based on dehydrated potato.

\section{Materials and Methods}

The experiment was conducted in the laboratory of the Department of Food Technology and Rural Industries, Bangladesh Agricultural University, Mymensingh. Bangladesh.

\section{Basic Procedure}

Potatoes of high yielding variety (Diamont) and other materials for making biscuit such as: wheat flour, potato flour, egg, sugar, baking powder, essences, dalda/soybean oil and salt were collected from different market of Mymensingh. The selected potatoes were cleaned and washed and then cut into pieces. The potato pieces were boiled in potable water for about 30 minutes. The boiled pieces were peeled manually and the potato pieces were sliced ( $3 \mathrm{~mm}$ thickness) and the slices were dipped into $0.1 \% \mathrm{KMS}$ solution for 5 minutes. The raw fresh potatoes were analyzed to determine the proximate compositions, such as; moisture content (Ranganna, 1992), ash content (AOAC, 1975), fat and protein content (AOAC, 2000), carbohydrate content (Pearson, 1976), and Vitamin C.

\section{Drying Methods}

Studies on dehydration of potatoes were carried out using Mechanical drying method by a cabinet dryer. The dryer consists of several chambers in which trays of samples were placed. A fan passed over a heater around the cabinet blew air over the samples undergoing dehydration. For determining the effect of temperature and loading density on drying rate, potatoes cut into different shape were taken for determination of moisture content. To observe the effect of thickness/loading density on drying rate constant, fresh potatoes of known moisture content and desired size $(3,5$ and $7 \mathrm{~mm}$ thick) were placed in trays and drying commenced in the drier at constant velocity and at a specific air dry bulb temperature $\left({ }^{0} \mathrm{C}\right)$. Moisture content at each time interval was determined gravimetrically and weight loss was used as a measure of the extent of drying. Again, to determine the effect of temperature on the drying rate of potatoes of constant size/loading were dried at three different temperatures $\left(45^{\circ} \mathrm{C}, 50^{\circ} \mathrm{C}\right.$ and $\left.60^{\circ} \mathrm{C}\right)$ at constant airflow.

\section{Analysis of Experimental Data}

To analyze the experimental data, Fick's 2nd law of diffusion has been used (Islam, 1980). Thickness dependence of drying rate was analyzed by plotting 'log' of drying rate constant ( $\mathrm{m}$ ) against 'log' of sample thickness (L); the relationship is derived from the solution of Fick's 2nd law of diffusion (Islam, 1980). To determine the temperature dependence of diffusion co-efficient, 'In' of diffusion co-efficient (De) was plotted against inverse absolute temperature $\left(\mathrm{Tabs}^{-1}\right)$ as per Arrhenius equation (Islam, 1980).

\section{Development of Dehydrated Potato Product (Biscuits)}

The wheat flour, potato powder and other ingredients were weighed accurately. The pre-weighed dry ingredients were mixed together. Fat $(40 \mathrm{~g})$ was added into the dry ingredients as per general formulation of biscuit making. Water was added accurately to form dough. The dough was then kneaded and rolled to uniform thickness of $\mathrm{mm}$. The biscuits were cut out with round biscuit cutters of $3.5 \mathrm{~cm}$ diameter. Then the biscuits were baked at $220^{\circ} \mathrm{C}$ for $10 \mathrm{~min}$, cooled to ambient temperature and packed in plastic bags. Three replications of each type biscuits were prepared.

\section{Sensory Evaluation}

The consumer's acceptability of developed products was evaluated by a taste testing panel. The hedonic rating test (1-9) was used to determine this acceptability and a score card was used for judging the products. The panelists were requested to assign appropriate colour, flavour, texture and overall acceptability of dehydrated potato products. 


\section{Results and Discussion}

\section{Effect of Loading Density on Drying Time}

To predict the influence of loading density on drying time, $1.2 \mathrm{~kg} / \mathrm{m}^{2}$ and $2.4 \mathrm{~kg} / \mathrm{m}^{2}$ potato of different shapes such as French cut, Cubes and Slices were dried at identical air dry bulb temperature $\left(55^{\circ} \mathrm{C}\right)$ at constant air velocity and the experimental data were analyzed by using equation (2) and moisture ratio (MR) versus drying time ( $\mathrm{hr}$ ) were plotted on a semi-log co-ordinate and regression lines were drawn (Fig. 1, 2 and 3). The following regression equations were developed:

\section{For French cut}

MR $=0.883 e^{-0.4185 x}$ for loading density $\left(1.2 \mathrm{~kg} / \mathrm{m}^{2}\right)$, at $55^{\circ} \mathrm{C}$

$\mathrm{MR}=0.8859 \mathrm{e}^{-0.362 \mathrm{x}}$ for loading density $\left(2.4 \mathrm{~kg} / \mathrm{m}^{2}\right)$, at $55^{\circ} \mathrm{C}$

\section{For Cubes,}

$\mathrm{MR}=0.8895^{-0.4621 \mathrm{x}}$ for loading density $\left(1.2 \mathrm{~kg} / \mathrm{m}^{2}\right)$, at $55^{\circ} \mathrm{C}$

$M R=0.8787 \mathrm{e}^{-0.423 \mathrm{x}}$ for loading density $\left(2.4 \mathrm{~kg} / \mathrm{m}^{2}\right)$, at $55^{\circ} \mathrm{C}$

\section{For Slices,}

MR $=0.9137^{-0.3724 x}$ for loading density $\left(1.2 \mathrm{~kg} / \mathrm{m}^{2}\right)$, at $55^{\circ} \mathrm{C}$

$\mathrm{MR}=0.9134 \mathrm{e}^{-0.3229 \mathrm{x}}$ for loading density $\left(2.4 \mathrm{~kg} / \mathrm{m}^{2}\right)$, at $55^{\circ} \mathrm{C}$

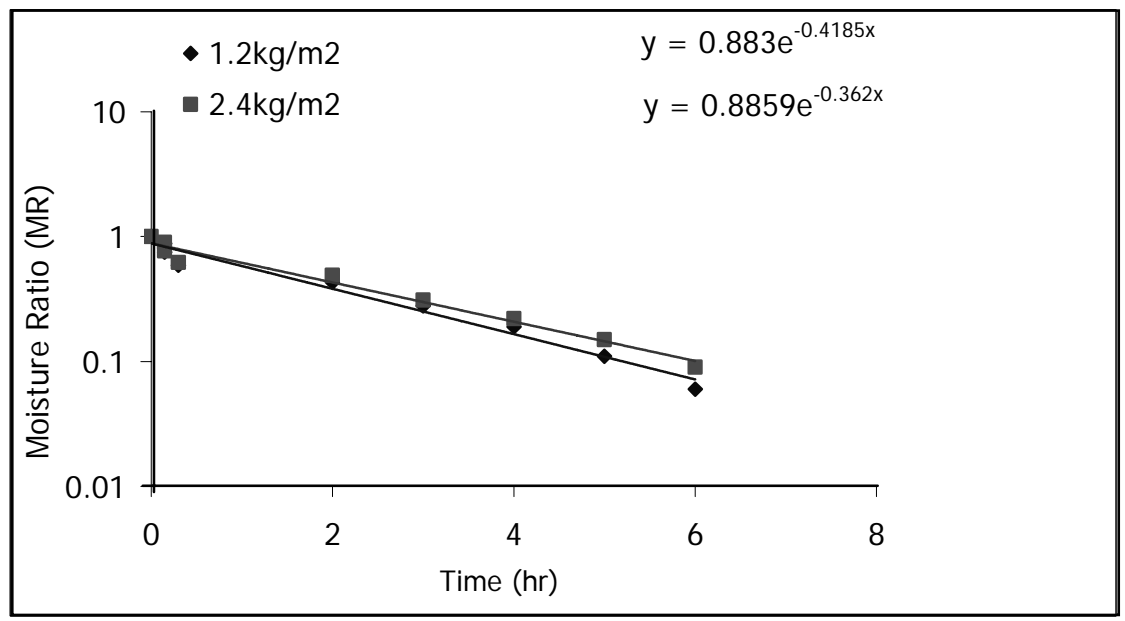

Fig. 1. Effect of loading density (French cut) on drying rate at $55^{\circ} \mathrm{C}$

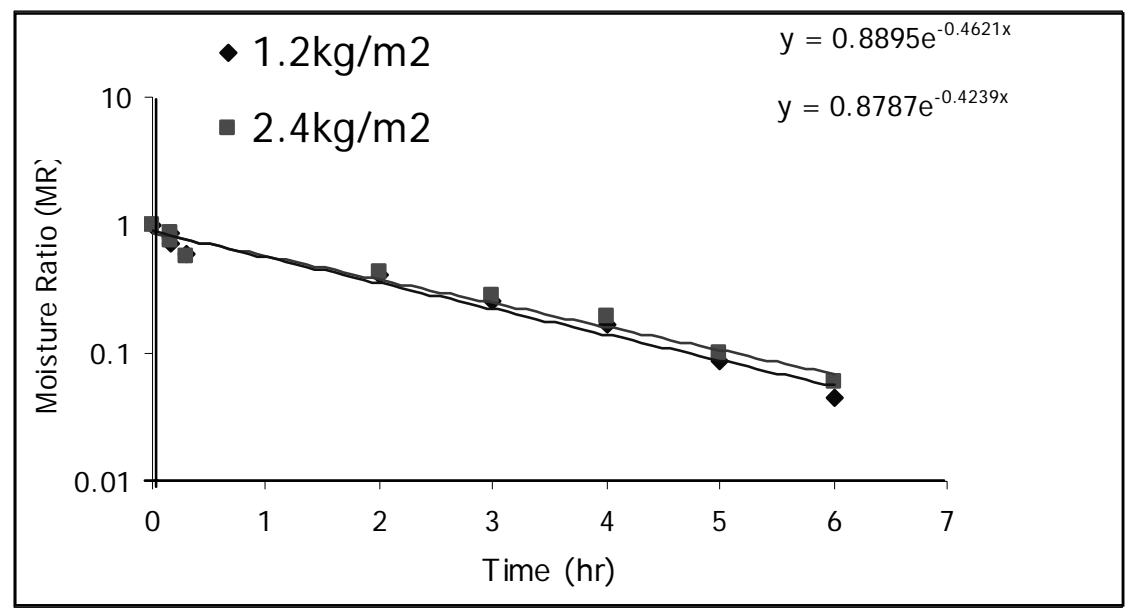

Fig. 2. Effect of loading density (Cubes) on drying rate at $55^{\circ} \mathrm{C}$ 
From the Fig. 1, 2 and 3 and above developed equation for French cut, Cube and Slice, it is seen that as loading density of French cut, Cube and Slice increases, the rate of drying decreases, but drying rate constant does not decrease proportionately as loading density increases. In case of French cut, using 1.2 $\mathrm{kg} / \mathrm{m}^{2}$ loading density, the rate constant was $0.4185 \mathrm{hr}^{-1}$ at $55^{\circ} \mathrm{C}$, whereas for twice the loading density at similar condition the rate constant was. $0.362 \mathrm{hr}^{-1}$. Similar situation are also observed in case of cubes and slices and may be attributed to more efficient utilization of the heat input in a thicker bed as noted by Islam and Flink (1982). This implies that at specific moisture ratio, more amount of water is evaporated per unit area for a given time from the samples with higher loading density that is also supported by lqbal and Islam (2005). It is also observed that cubes dried faster and successively followed by French cut and slices and this behaviour may be related to surface area, airflow related phenomenon as noted by Islam (1980). This phenomenon can be advantageously used for increased dryer throughout. However, care should be taken not to increase loading density to such an extent as to increase drying time to a level at which the products are spoiled.

\section{Influence of Thickness on Drying Rate}

To investigate the effect of thickness on drying behavior of $3 \mathrm{~mm}, 5 \mathrm{~mm}$ and $7 \mathrm{~mm}$ slices of HYV potato (Diamont) were dried at a constant air dry bulb temperature of $50^{\circ} \mathrm{C}$. The results were analyzed by using equation 2 and are shown in Fig 6. For three different thicknesses the developed equations are:

$\mathrm{MR}=0.9774^{\mathrm{e}-0.0878 \mathrm{x}}$ (for $3 \mathrm{~mm} ; \mathrm{t}=\mathrm{hr}$ )
$\mathrm{MR}=0.9670^{\mathrm{e}-0.1198 \mathrm{x}}$ (for $5 \mathrm{~mm} ; \mathrm{t}=\mathrm{hr}$ )
$\mathrm{MR}=0.9742^{\mathrm{e}-0.0686 \mathrm{x}}$ (for $7 \mathrm{~mm} ; \mathrm{t}=\mathrm{hr}$ )

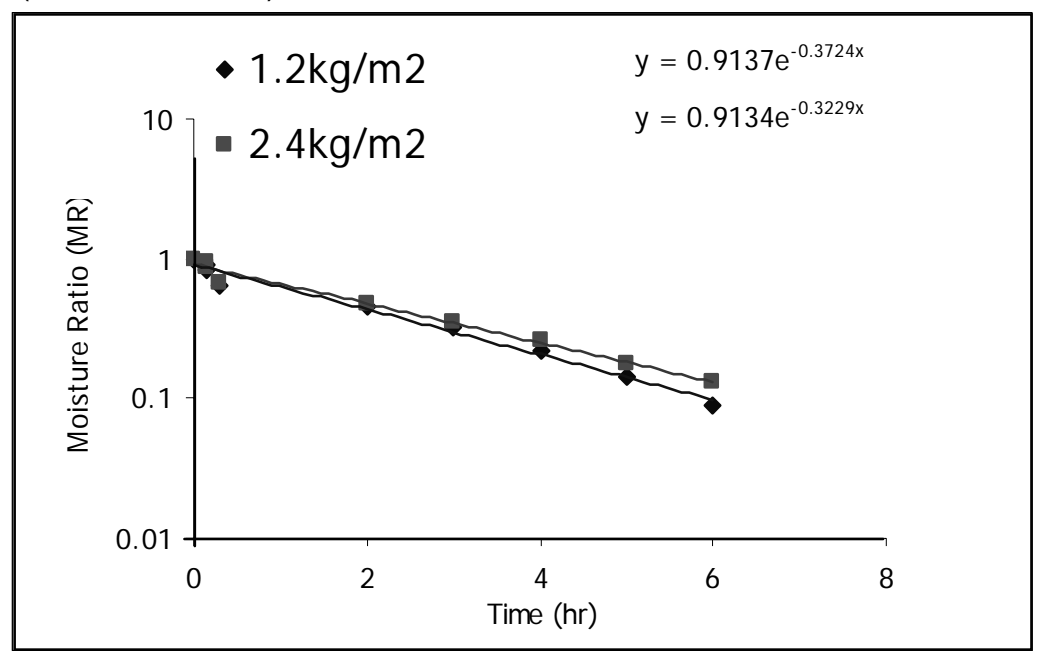

Fig. 3. Effect of loading density (Slices) on drying rate at $55^{\circ} \mathrm{C}$

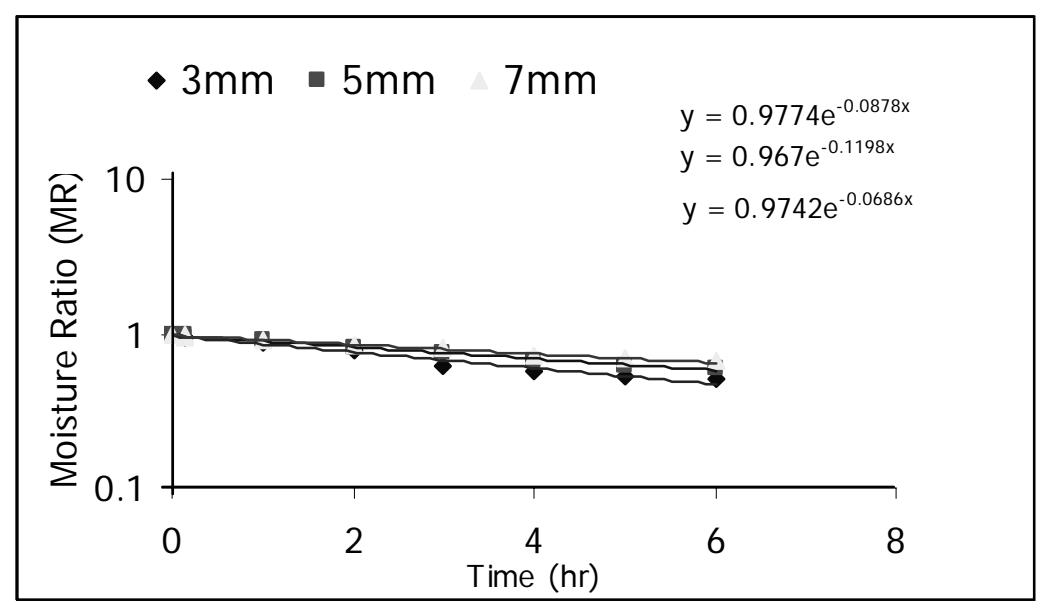

Fig. 4. Effect of thickness on drying rate at $50^{\circ} \mathrm{C}$ 
From the above equations and Fig. 4, it can be clearly seen that the thickness of the sample influences directly on drying time. The relationship between sample thickness $(L)$ and drying rate constant $(\mathrm{m})$ was developed (Fig. 5) from the power law equations which is as follows:

$$
\mathrm{m}=0.1212 \mathrm{~L}^{-0.261}
$$

It is found from the above equations that the value of ' $n$ ' of the power law equation is 0.261 at $50^{\circ} \mathrm{C}$. It is lower than 2 as predicted by equation (5) and it indicates that the external resistance to mass transfer is highly significant under the given conditions. This also indicates that higher airflow rates will give higher drying rates. Iqbal and Islam (2005) determine ' $n$ ' value of 0.287 and 0.4105 for cauliflower and cucumber respectively while Islam (1980) found an ' $n$ ' value of 1.70 during drying of potato using higher airflow rates $(2.5 \mathrm{~m} / \mathrm{s})$ and Ayesha et al. (2012) observed an $n$ value of 0.459 during the drying of local variety potato (Lalpakri) at $50^{\circ} \mathrm{C}$. The above discrepancy of ' $n$ ' value is mainly due to airflow rate and thickness and demonstrates the relative importance of external or internal mass transfer resistance. However, product structure and composition and simultaneous heat and mass transfer effects also play important roles in this regard. Islam (1980) showed that by taking into account of the simultaneous heat and mass transfer effect value of ' $n$ ' could be corrected to 2 from 1.7.

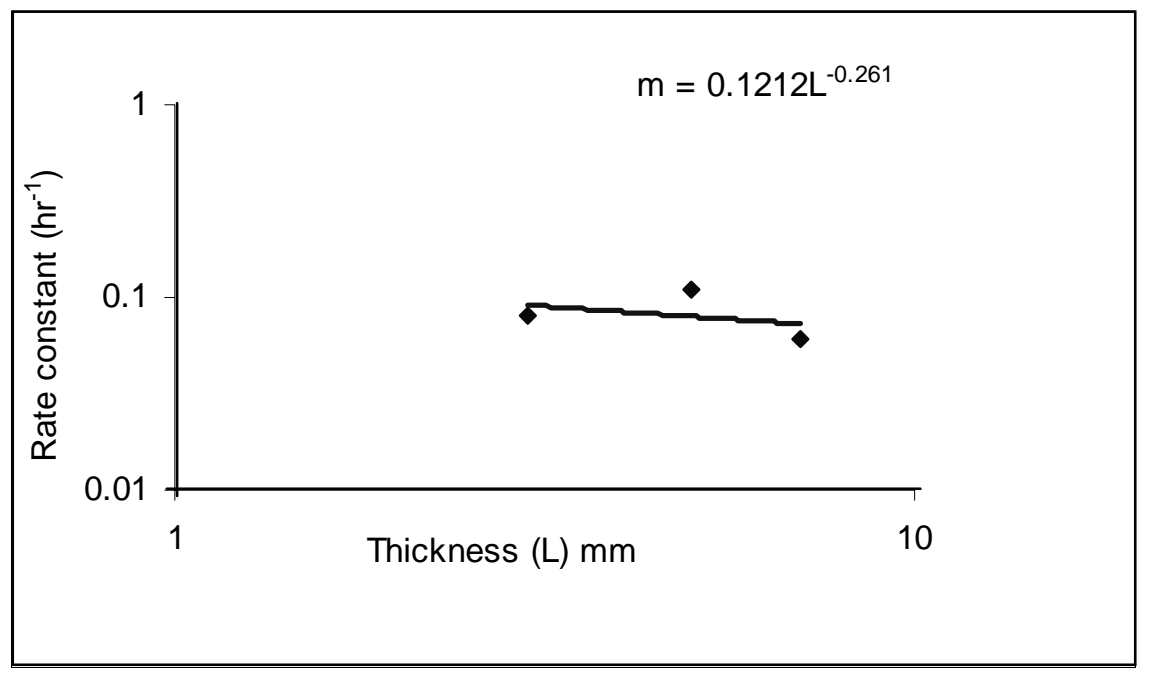

Fig. 5. Influence of thickness on drying rate constant at $50^{\circ} \mathrm{C}$

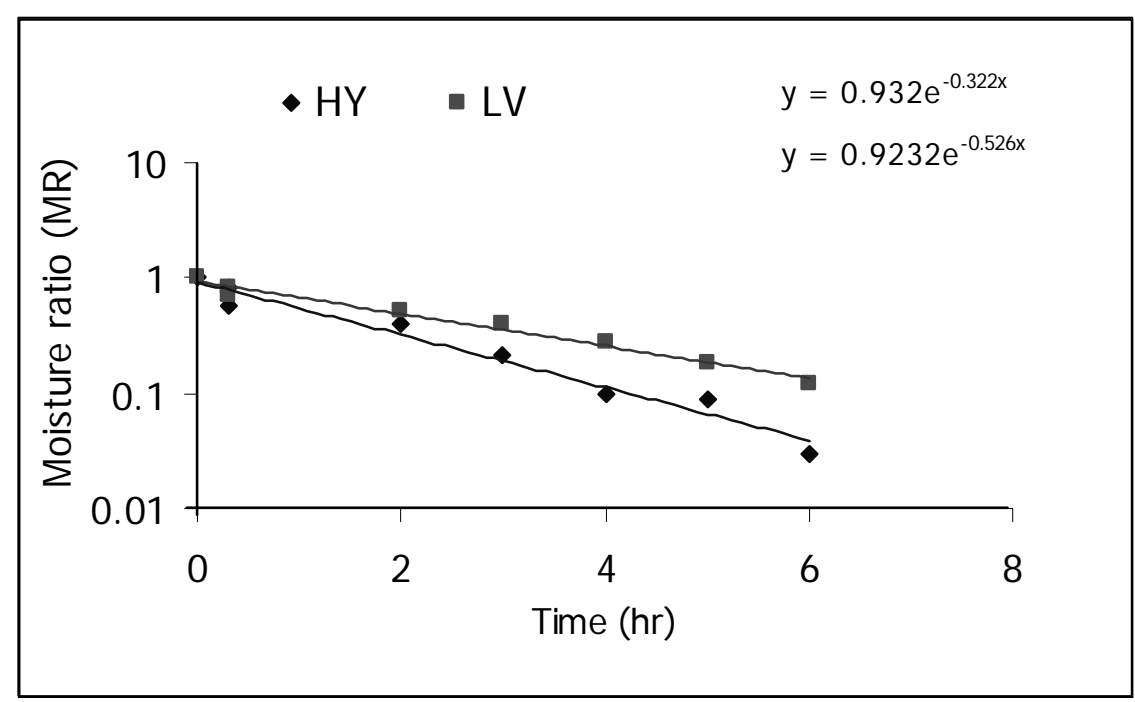

Fig. 6. Influence of variety (HYV and LV) on drying rate at $60^{\circ} \mathrm{C}$ 


\section{Influence of Variety on Drying Rate}

To observe the influence of variety on drying behaviour of potatoes of high yielding variety (HYVDiamont), $5 \mathrm{~mm}$ of thickness (similar) at two different air dry bulb temperature $\left(45^{\circ} \mathrm{C}\right.$ and $\left.60^{\circ} \mathrm{C}\right)$ and constant air velocity were dried in a mechanical dryer. It was found that the average moisture content of HYV was higher than that of LV. The experimental drying rate were analyzed by using Fick's 2nd law of diffusion and plots of moisture ratio versus drying time were made on semi-log scale and the following regression lines (Fig. 6 and 7 ) and equations are found:

At $60^{\circ} \mathrm{C}, 5 \mathrm{~mm}$ thickness

$\mathrm{MR}=0.9232 \mathrm{e}^{-0.526 \mathrm{x}}$ for HYV and MR $=0.932 \mathrm{e}^{-0.322 \mathrm{x}}$ for LV

At $45^{\circ} \mathrm{C}, 5 \mathrm{~mm}$ thickness

MR $=0.9787 \mathrm{e}^{-0.4055 x}$ for HYV and MR $=0.9663 \mathrm{e}^{-0.2267 x}$ for LV

From the figure 6 and 7 and the above develop equations, it is revealed that the HYV had increased rate of drying thus also higher drying rate constant than that of LV. It is also seen that increase in temperature gives increased drying rate for both the varieties.

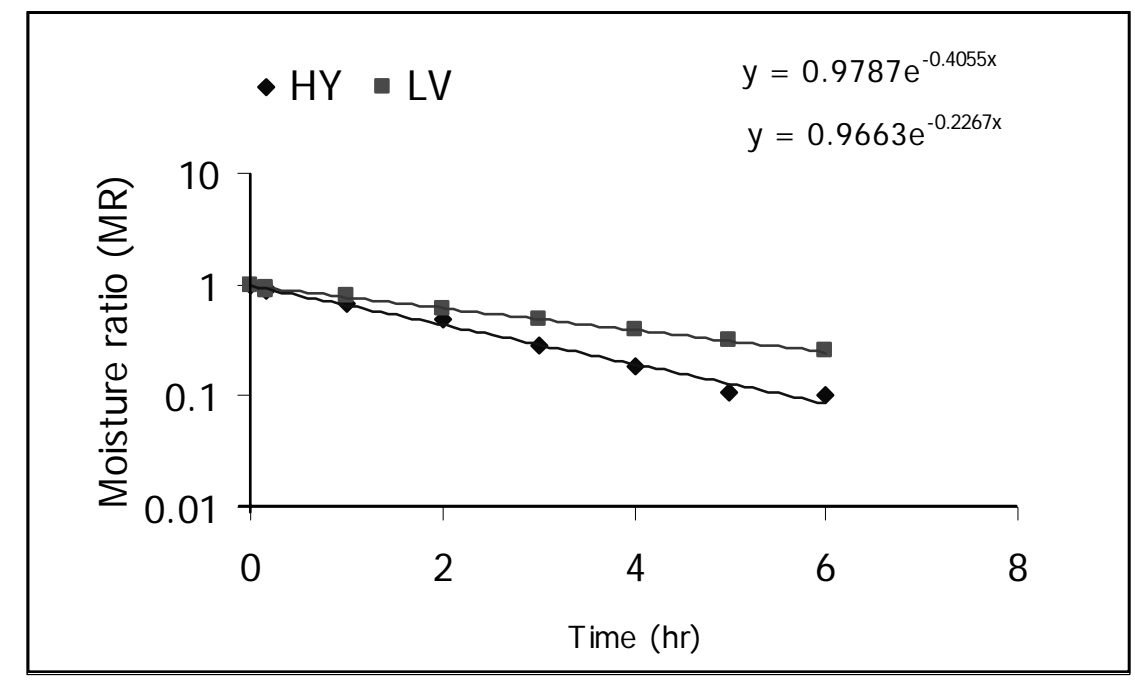

Fig. 7. Influence of variety (HYV and Local) on drying rate at $45^{\circ} \mathrm{C}$

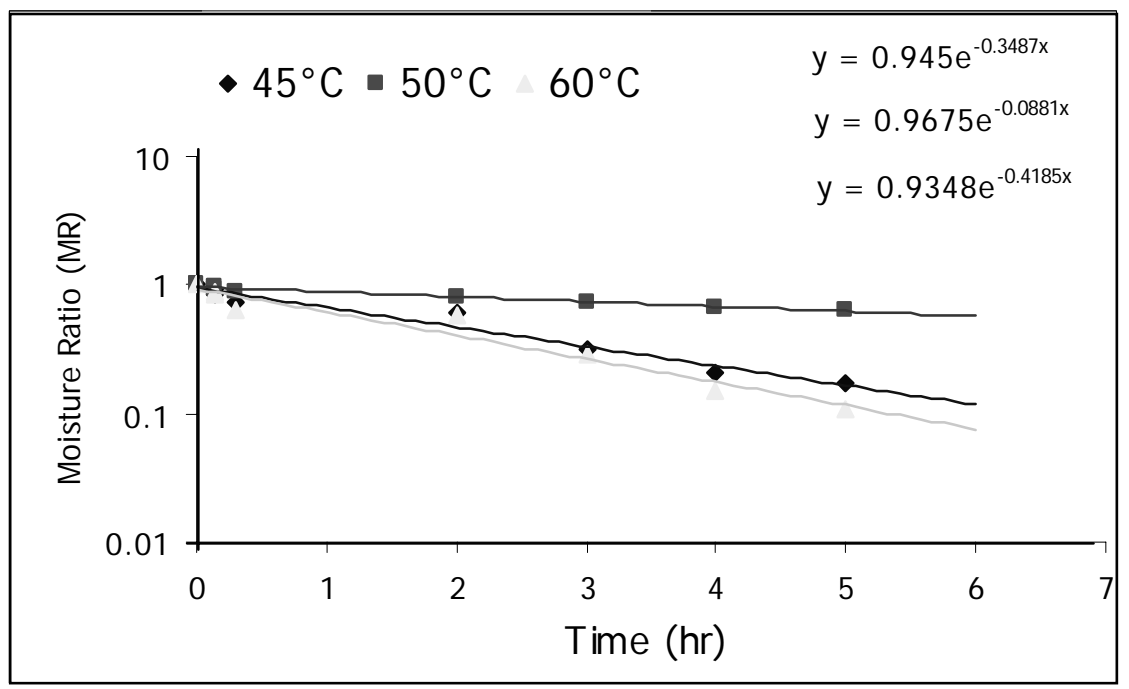

Fig. 8. Influence of temperature on drying rate for $5 \mathrm{~mm}$ slices of potatoes 


\section{Influence of Temperature on Drying Time}

To determine the influence of temperature on drying time potatoes were dried in the mechanical dryer at $45^{\circ} \mathrm{C}, 50^{\circ} \mathrm{C}$ and $60^{\circ} \mathrm{C}$ using constant sample thickness ( $5 \mathrm{~mm}$ slice). Analyzing the drying data by using equation (2) and plots of moisture ratio versus drying time on semi-log scale, the regression lines were drawn (Fig. 8) and the developed equations are given here under:

$\mathrm{MR}=0.945 \mathrm{e}^{-0.3487 \mathrm{x}}$ for $5 \mathrm{~mm}$ slice at $45^{\circ} \mathrm{C}$

$\mathrm{MR}=0.9675 \mathrm{e}^{-0.0881 \times}$ for $5 \mathrm{~mm}$ slice at $50^{\circ} \mathrm{C}$

MR $=0.9348 \mathrm{e}^{-0.4185 \mathrm{x}}$ for $5 \mathrm{~mm}$ slice at $60^{\circ} \mathrm{C}$

From the figure 8 and the above equations it is observed that the moisture ratio (MR) decreases with time and time to dry to specific ratio decreases with increasing temperature. Thus, higher temperature would give faster drying rate. At very high temperature and low humidity drying rate may initially increased, but at drying progresses resultant case hardening would reduced drying rate and deteriorate the quality of the product. High temperature also may scorch the product and thus selection of optimum temperature for drying is of significance during particularly, mechanical drying with counter current operation (Karel et al. 1975, Potter, 1978 and Islam, 1980). Drying rate constant to develop the Arrhenius type relationships that are determined by regression equation, the diffusion coefficient were determined (Table 1). Diffusion coefficient (De) versus inverse absolute temperature $\left(T_{\mathrm{abs}}{ }^{-1}\right)$ were plotted on a semi-log scale and regression lines were drawn. From the slope of the resultant straight line (Fig.9), activation energy $\left(E_{a}\right)$ for diffusion of water from Diamont variety of potato was calculated and found to be $7.98 \mathrm{Kcal} / \mathrm{g}-\mathrm{mole}$. The calculated activation energy is higher than $5.60 \mathrm{Kcal} / \mathrm{gm}$-mole of activation energy for diffusion of water from potato of local variety (Lalpakri) by Ayesha Sarker (2009) and Ayesha Sarker et al. (2012), those found by Afzal Babu et al. (1997) for onion (26.83 Kcal/g-mole), that for cucumber (8.50Kcal/g-mole) and cauliflower $(7.76 \mathrm{Kcal} / \mathrm{g}$-mole) found by Iqbal (2003) but higher than that $(4.4 \mathrm{Kcal} / \mathrm{g}$-mole) found for mango by Islam et al. (1997). The differences in activation energy might result from differences in product characteristics as well as process parameters, temperature employed for drying etc. as noted by Islam (1980) and Iqbal and Islam (2005).

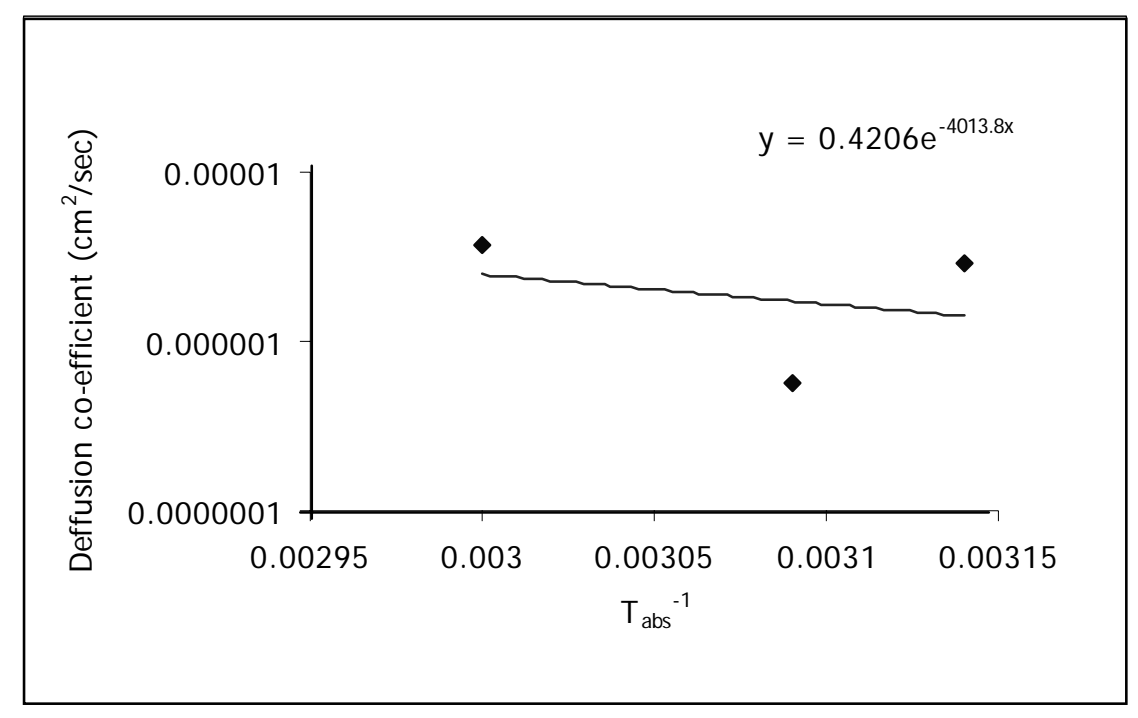

Fig. 9. Effect of temperature on diffusion co-efficient of HYV 


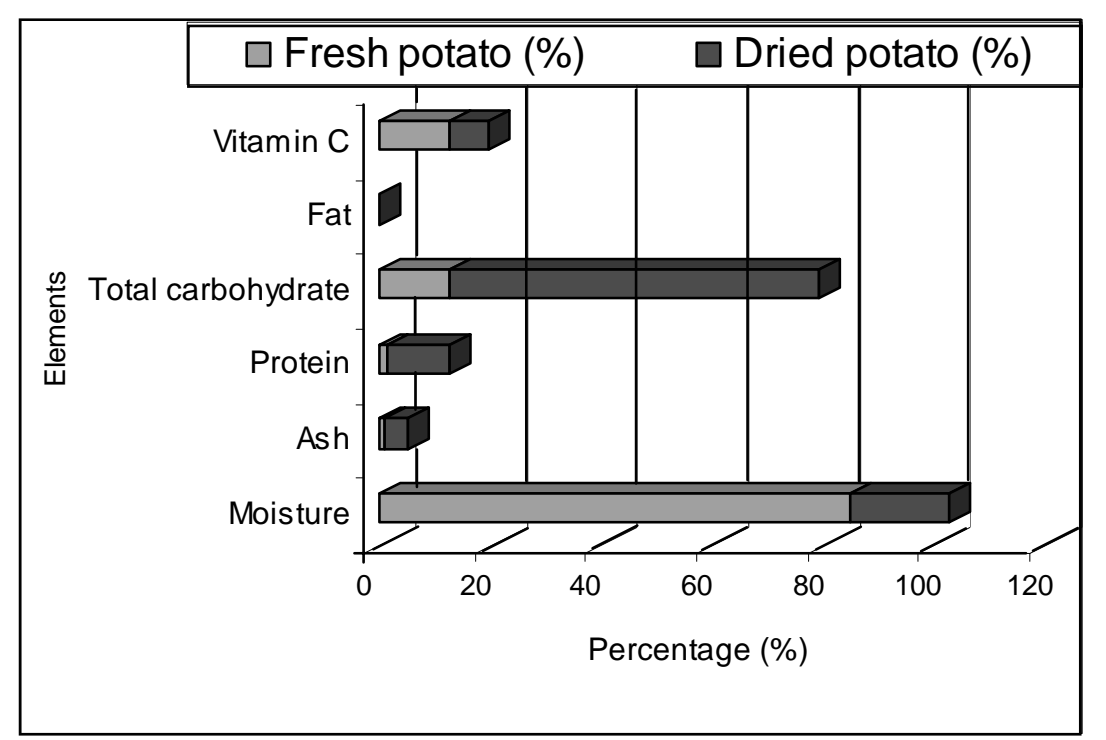

Fig.10. Comparison of fresh and dry potato (Diamont)

The dependence of diffusion co-efficient on absolute temperature can be represented as: $D_{e}=0.4206 e^{-4013.8 x}$

Where, $\mathrm{D}_{\mathrm{e}}=$ Diffusion co-efficient $\left(\mathrm{cm}^{2} / \mathrm{s}\right)$ and $\mathrm{T}_{\text {abs }}=$ Absolute temperature $\left({ }^{0} \mathrm{~K}\right)$

Table 1. Drying parameters of mechanical dried potato

\begin{tabular}{|c|c|c|c|c|c|c|}
\hline $\begin{array}{l}\text { Thickness } \\
\text { (mm) }\end{array}$ & $\begin{array}{c}\text { Shape of } \\
\text { object }\end{array}$ & Temperature & $\begin{array}{l}\text { Slope } \\
\left(\mathrm{min}^{-1}\right)\end{array}$ & $\begin{array}{l}\text { Diffusion } \\
\text { co-efficient } \\
\left(\mathrm{cm}^{2} / \mathrm{s}\right)\end{array}$ & $\begin{array}{c}\text { Value of } \\
\text { exponent } \\
\text { (n-value) }\end{array}$ & $\begin{array}{c}\text { Activation } \\
\text { energy (Ea) } \\
\text { Kcal/gm-mole }\end{array}$ \\
\hline 3 & Slice & $50^{\circ} \mathrm{C}$ & $1.46 \times 10^{-3}$ & $2.22 \times 10^{-1}$ & \multirow{8}{*}{0.261} & \multirow{8}{*}{7.98} \\
\hline 5 & Slice & $50^{\circ} \mathrm{C}$ & $1.99 \times 10^{-3}$ & $8.43 \times 10^{-1}$ & & \\
\hline 7 & Slice & $50^{\circ} \mathrm{C}$ & $1.14 \times 10^{-3}$ & $9.47 \times 10^{-7}$ & & \\
\hline 8 & French cut & $55^{\circ} \mathrm{C}$ & $6.97 \times 10^{-3}$ & $7.54 \times 10^{-6}$ & & \\
\hline 8 & Cube & $55^{\circ} \mathrm{C}$ & $7.70 \times 10^{-3}$ & $8.33 \times 10^{-6}$ & & \\
\hline 8 & Slice & $55^{\circ} \mathrm{C}$ & $6.20 \times 10^{-3}$ & $6.71 \times 10^{-6}$ & & \\
\hline 5 & Slice & $45^{\circ} \mathrm{C}$ & $6.75 \times 10^{-3}$ & $2.85 \times 10^{-6}$ & & \\
\hline 5 & Slice & $60^{\circ} \mathrm{C}$ & $8.76 \times 10^{-3}$ & $3.70 \times 10^{-6}$ & & \\
\hline
\end{tabular}

\section{Comparison of Composition of Fresh and Dried HYV Potatoes (var. Diamont)}

The fresh potatoes contained $85 \%$ moisture, $0.95 \%$ ash, $1.23 \%$ protein, $12.72 \%$ carbohydrate, $0.10 \%$ fat and $12.5 \%$ vitamin $\mathrm{C}$, where as the mechanical dried potatoes contained $17.81 \%$ moisture, $4.38 \%$ ash ash, $11.38 \%$ protein, $66.39 \%$ carbohydrate, $0.045 \%$ fat and $7.02 \%$ vitamin C (Fig.-10). During drying, most of water in the potatoes is vaporized so the moisture content is so less and consequently solid content increased. Thus increased solid content results the increased protein, ash, carbohydrates contents. The fat content decreased in the dried sample which may be due to the oxidation of fat during drying.

\section{Development of Product}

The dried potatoes were grinded in a laboratory grinder and potato powder was obtained. Then biscuit were prepared by mixing wheat flour and potato powder at different ratio. The products are then tested organoleptically. 


\section{Sensory Evaluation for Potato Flour 'Biscuit'}

The mean score for colour, flavour, texture and overall acceptability of dehydrated potato 'biscuit' are shown in Table 2. A two way analysis of variance (ANOVA) was carried for colour preference, flavour, texture and overall acceptability of the sample biscuits and $F$ values were tabulated at $5 \%$ level of significance for all the sensory attributres. Te caloculated F-values were higher for all the attributes. This meant that the panelist did not equally accept the attributes.

Table 2. Mean score for colour, flavour, texture and overall acceptability of potato flour 'biscuit'

\begin{tabular}{|c|c|c|c|c|}
\hline \multirow{2}{*}{ Sample } & \multicolumn{4}{|c|}{ Sensory attributes } \\
\cline { 2 - 5 } & Colour & Flavour & Texture & Overall acceptability \\
\hline Sample 205 & $8.1 \mathrm{a}$ & $7.3 \mathrm{~b}$ & $6.8 \mathrm{~b}$ & $7.1 \mathrm{~b}$ \\
\hline Sample 415 & $7.7 \mathrm{ab}$ & $7.7 \mathrm{~b}$ & $8.2 \mathrm{a}$ & $7.8 \mathrm{a}$ \\
\hline Sample 525 & $7.1 \mathrm{~b}$ & $8.4 \mathrm{a}$ & $8.2 \mathrm{a}$ & $8.0 \mathrm{a}$ \\
\hline LSD $_{(0.05)}$ & 0.75 & 0.59 & 0.98 & 0.49 \\
\hline
\end{tabular}

Sample means having the same letter suffix do not differ at the $5 \%$ level of significance.

Sample 205: Potato flour (PF) : Wheat flour (WF) $=1.5: 1$

Sample 415: Potato flour (PF) : Wheat flour (WF) $=1: 1.5$

Sample 525: Potato flour (PF) : Wheat flour (WF) $=1: 1$

As shown in Table 2, the sample 205 scored significantly better for colour but the sample 525 scored also significantly better for flavour, texture and overall acceptability while the sample 415 secured the $2^{\text {nd }}$ highest score. Incase of the sample 205, all the attributes except colour secured the lowest scores. From view points of overall acceptability and other considerations sample 525 appears to be the most acceptable product securing the highest score (8.2 out of 9) among the samples and the product is ranked as "like very much" and was followed by biscuit made of 1:1 (dehydrated potato : wheat flour), while the lowest value (6.8) was found in case of product of sample 205 and ranked as "like slightly". However, the details formulation of potato product biscuits were presented in the following (Table 3).

Table 3. Detail formulation for prepared biscuit for the samples 205, 415 and 525

\begin{tabular}{|l|c|c|c|}
\hline Sample & $\begin{array}{c}\text { Sample 205 } \\
\text { (PF : WF = 1.5:1) }\end{array}$ & $\begin{array}{c}\text { Sample 415 } \\
\text { (PF : WF = 1:1.5) }\end{array}$ & $\begin{array}{c}\text { Sample 525 } \\
\text { (PF : WF = 1:1) }\end{array}$ \\
\hline Potato flour & $150 \mathrm{~g}$ & $100 \mathrm{~g}$ & $100 \mathrm{~g}$ \\
\hline Wheat flour & $100 \mathrm{~g}$ & $150 \mathrm{~g}$ & $100 \mathrm{~g}$ \\
\hline Fat (hydrogenated) & $100 \mathrm{~g}$ & $100 \mathrm{~g}$ & $80 \mathrm{~g}$ \\
\hline Suger & $100 \mathrm{~g}$ & $100 \mathrm{~g}$ & $80 \mathrm{~g}$ \\
\hline Salt & $1.75 \mathrm{~g}$ & $1.75 \mathrm{~g}$ & $1.40 \mathrm{~g}$ \\
\hline Milk powder & $10 \mathrm{~g}$ & $10 \mathrm{~g}$ & $30 \mathrm{~g}$ \\
\hline Water & $37.5 \mathrm{~g}$ & $37.5 \mathrm{~g}$ & $3.0 \mathrm{~g}$ \\
\hline Bakary powder & $3.75 \mathrm{~g}$ & $3.75 \mathrm{~g}$ & $1.0 \mathrm{~g}$ \\
\hline Ammonium Bicarbonate & $1.25 \mathrm{~g}$ & $1.25 \mathrm{~g}$ & \\
\hline
\end{tabular}

\section{Conclusion}

Based on the above findings, it was found that the diffusion co-efficient increased with the increase in temperature. Results revealed that with the increase of loading density of different shape of potatoes, the drying rate decreases but not proportionately decrease as bed thickness increases. The power law equations which described the relationship between drying rate constant and thickness gave an $n$-value of 0.4586 for HYV of potato (Diamont). The activation energy $\left(E_{a}\right)$ for diffusion of water from potatoes of high yielding variety from the exponential relationship between diffusion co-efficient $\left(D_{e}\right)$ versus inverse absolute temperature $\left(T_{a b s}{ }^{-1}\right)$ was found $7.98 \mathrm{Kcal} / \mathrm{gm}$-mole. Results from the organoleptic taste tests demonstrated that among biscuits made of various proportion of potato flour and wheat flour, test panel showed that biscuit made of equal proportion (1:1) of potato flour and wheat flour secured the highest 
score (8.0) and was ranked as "like very much". All the other samples of each type of product were also accepted by the panelists either as "like moderately" or "like slightly". The generated information of the present study on kinetics of dehydration of potato and development of baked product based on dehydrated potato will be very helpful for students, future researchers and policy makers as well. However, further research in this area is urgent.

\section{Acknowledgements}

The authors thank and grateful to NSICT authority as the research was supported by a research fellowship from NSICT, the National Science and Information and Communication Technology, Ministry of Science and Information and Communication Technology, Peoples Republic of Bangladesh.

\section{References}

Afzal Babu, S.M.M., Kowser Sarker, M.A.S., and Islam, M.N. 1997. Kinetics of mechanical, solar and drying of onion. Bangladesh J. of Agril. Engg., 8 (1\&2): 49-61.

AOAC. 1975. Official Methods of Analysis. Fourteenth edition. Association of Official Analytical Chemists. Washington, D.C. USA.

AOAC. 2000. Official Methods of Analysis, Seventeenth edition. Association of Official Analytical Chemists, Washington, D.C. USA.

Ayesha Sarker. 2009. Development of baked products based on cooked and dehydrated potato. An MS thesis submitted at Department of Food Technology and Rural Industries, Bangladesh Agricultural University, Mymensingh, pp.96.

Ayesha Sarker, Islam, M.N. and Shaheb, M.R. 2012. A study on the drying behaviour of a local variety (Lalpakri) of potato (Solanum tuberosum L.) Bangladesh J. of Agril. Res. 37(3): 505-514.

BBS (Bangladesh Bureau of Statistics). 2010. Year Book of Agricultural Statistics of Bangladesh. Statistics Division, Ministry of Planning, Govt. of the People's Republic of Bangladesh, Dhaka. p.134.

Carillo, P., Cacace, D., De Rosa, M., De Martino, E., Cozzolino, C., Nacca, F., D’Antonio, R., and Fuggi, A. 2009, Process optimization and physicochemical characterization of potato powder. International J. of Food Sci. \& Technol., 44: $145-151$. doi: 10.1111/j.1365-2621.2007.01696.x.

Falade, K.O. and Solademi, O.J. 2010, Modeling of air drying of fresh and blanched sweet potato slices. International J. of Food Sci. \& Technol., 45: 278-288. doi: 10.1111/j.1365-2621.2009.02133.x.

FAO (Food and Agriculture Organization). 2008. FAO resolution, The International Year of Potato 2008. Hidden Treasure. www.potato2008.org, 1-8.

Hossain, M.A. and Miah, M.A.M.. 2010. Post-harvest losses and technical efficiency of potato storage systems in Bangladesh. Technical Report submitted to FAO, Bangladesh. Available at: http://www.fao.org/inpho/content/conpend/text

Iqbal, A. 2003. Processing and preservation of cauliflower and cucumber by dehydration and fermentation. M.S. thesis, Dept. of Food Technology and Rural Industries, Bangladesh Agricultural University, Mymensingh.

Iqbal, A., and Islam, M.N. 2005. Dehydration kinetics of cauliflower. Bangladesh J. Crop Sci. 16(1): 113-122.

Islam, M.N. 1980. Use of Solar energy for development of self stable potato products. Ph.D. Thesis., Royal Veterinary and Agricultural University, Copenhagen, Denmark.

Islam, M.N., and Flink, J.M. 1982. Dehydration of potato-II: Osmotic concentration and its effect on air-drying behaviors. J. of Food Technol., 17: 387-403.

Islam, M.N., Uddin, M.B. and Islam, N.M. 1997. Development of self-stable dehydration mango products. Bangladesh J. Agril. Engg. 4 (1\&2): 65-73.

Karel, M., Fennema, O.R., and Lund, D.B. 1975. Principles of Food Science, Part-II, Physical principles of food preservation. Marcel Dekker, Inc. New York and Basel., 133-139, 205.

McMinn, W.A.M., and Magee, T.R.A. 1997. Quality and physical structure of a dehydrated starch-based system. Journal of Drying Tech. United Kingdom. 6(8): 1961-1971.

Miah, M.A.M., Hossain, S., Hossain, T. M. B., Rahman S. and et al. 2011. Assessment of potato farmers' perceptions on abiotic stresses and implications for potato improvement research in Bangladesh: a baseline survey. Research report submitted to International Potato Centre (CIP), Lima, Peru.

Pearson, D. 1976. The dictionary of Nutrition and Food Technoloy. $5^{\text {th }}$ Edn. Butter Worth Publication. London.

Potter, N.N. 1978. Food Science, CBS publishers and distributors, Shahdara, Delhi

USPB (United States of Potato Board), 2005. Dehydrated Potatoes: Food Function Advances. Discover how dried potato products are enhancing everything from baked goods to frozen foods, to snacks. Asia Food J. (Nov. 1). www.sfaeindia.com./does. Market intelligence system baseline data for potato and onion. April 2012. 